\title{
Preparation of Nanostructured Pd-C-Ru Composite Electrodes for Alcohol Electrooxidations. Part-II: A Study of Methanol Oxidation by Cyclic Voltammetry and Impedance Spectroscopy
}

\author{
Anindita, R. Awasthi, Madhu and R.N. Singh* \\ Department of Chemistry, Centre of Advanced Study, Faculty of Science, Banaras Hindu University, Varanasi-221005, \\ India
}

\begin{abstract}
Ternary nanocomposites of $\mathrm{Pd}, \mathrm{Ru}$ and nanocarbon $(\mathrm{NC})$ have been prepared by the sodium borohydride reduction method and investigated by cyclic voltammetry (CV), electrochemical impedance spectroscopy (EIS) and chronoamperometry techniques for their use as electrocatalysts for the methanol oxidation reaction (MOR). The study have shown that with addition of ruthenium from 1 to $50 \mathrm{wt} \%$, in the Pd- $0.5 \mathrm{wt} \% \mathrm{C}$ composite, the rate of MOR initially increases, attains maximum and declines thereafter. Among ternary composites investigated, the Pd- $0.5 \mathrm{wt} \% \mathrm{C}-20 \mathrm{wt} \%$ $\mathrm{Ru}$ composite exhibited the greatest electrocatalytic activity. This electrode has approximately three times higher electrocatalytic activity than the base electrode (Pd- $0.5 \mathrm{wt} \% \mathrm{C})$. The electrochemical active surface area $\left(\approx 133 \mathrm{~m} / \mathrm{g}_{\mathrm{Pd}}\right)$ and the percentage utilization of Pd (30\%) of the Pd- $0.5 \mathrm{wt} \% \mathrm{C}-20 \mathrm{wt} \% \mathrm{Ru}$ electrode were also more than 5 times higher than that of the base electrode.
\end{abstract}

Keywords: Methanol electrooxidation, electrocatalytic properties, nanocomposites, direct methanol fuel cells (DMFCs).

\section{INTRODUCTION}

Direct methanol fuel cells (DMFCs) have received considerable attention for both mobile and stationary applications. The large majority of DMFCs operates in acid media and use precious Pt or its alloys as anode catalysts [1]. Pt has the highest catalytic activity for the methanol oxidation reaction (MOR), but its surface is soon poisoned by strongly adsorbed $\mathrm{CO}$ molecule coming from the dissociation of methanol [2]. Efforts have been made to improve the performance and reduce the cost of DMFCs. For the purpose, $\mathrm{Pt}$ metals have been produced in finely dispersed form on various conductive surfaces [1,3-5]. Also, to overcome the effect of $\mathrm{CO}$ poisoning, $\mathrm{Pt}$ is alloyed with a second metal (Ru, Sn, Pd, Rh or Mo) [1, 2, 6-10]. PtRu bifunctional catalysts are presently the most active for the methanol oxidation reaction (MOR), with $\mathrm{Ru}$ believed to serve the role of removing $\mathrm{CO}_{\text {ads }}$ as $\mathrm{CO}_{2}$ [10]. The research work has also been carried out to obtain a suitable replacement for Pt. Several non platinum metals have recently been investigated as electrocatalysts for methanol/ethanol oxidation reaction (MOR/EOR) in alkaline media $[11,12]$. Among them Pd is considered as the most promising electrode material for use in an alkaline DAFC (direct alcohol fuel cell) [11]. Efforts are continued to enhance its electrocatalytic activity through improvement in its geometrical and electronic properties.

$\mathrm{Pd}$ nanoparticles have been obtained alone or alloyed/doped with other metals on carbon materials, such as C $[13,14]$, CMSs (carbon microspheres) [15], CHCs (coin

*Address correspondence to this author at the Department of Chemistry, Centre of Advanced Study, Faculty of Science, Banaras Hindu University, Varanasi-221005, India; Tel: +91-542-6701596; Fax: +91-542-2368127;

E-mails: rnsbhu@rediffmail.com,rns_bhu@rediffmail.com like hollow carbons) [16], HCSs (ultrahigh-surface hollow carbon spheres) [17], CNTs (carbon nanotubes) [18-20], and NWAs (nanowire arrays) [21,22]. Other materials than carbon blacks, such as $\mathrm{TiO}_{2}$ nanotubes [23], vanadium oxide nanotubes [24], etc. were also used as supports for Pd catalysts. Pd catalysts mixed with metal oxides were also obtained on carbon black $[25,26]$ or other carbon materials [27] and studied for alcohol electrooxidation. These works have comprehensively been reviewed by Bianchini and Shen [11].

Recently, Singh et al. [28] studied the oxidation of methanol/ethanol on binary composites of $\mathrm{Pd}$ and nanocarbon (NC) in $1 \mathrm{M} \mathrm{KOH}$ and observed that the Pd$0.5 \mathrm{wt} \% \mathrm{NC}$ was the greatest active. To improve the electrocatalytic activity of this composite electrode further, ruthenium was added from 1 to $50 \mathrm{wt} \%$ and investigated structural and electrocatalytic properties of the new ternary products, so derived, towards alcohol oxidation. Very recently, we reported [29] the study of structural and electrocatalytic properties of $\mathrm{Pd}-0.5 \mathrm{wt} \% \mathrm{C}-\mathrm{Ru}$ composites for the EOR in $1 \mathrm{M} \mathrm{KOH}$. In this paper (Part-II), we report the electocatalytic activities of these composite materials towards the MOR in $1 \mathrm{M} \mathrm{KOH}$. The electrochemical active surface area (EASA) of catalyst electrodes as well as the percent utilization of Pd in different composites, which were not reported in Part-I, are also determined and described in this paper.

\section{EXPERIMENTAL}

Ternary composites of Pd, nanocarbon (NC) and Ru with molecular formula, (99.5-x)wt \%Pd- $0.5 \mathrm{wt} \% \mathrm{C}$-xwt \% Ru (x $=1,2,5,10,20,30$ and 50) were synthesized by sodium borohydride reduction method as previously described [29]. The NC powders (Aldrich, 99+\%, particle size $\leq 30 \mathrm{~nm}$, BET surface area $>100 \mathrm{~m}^{2} \mathrm{~g}^{-1}$ ) used in preparation of 
composites were activated by refluxing in concentrated $\mathrm{HNO}_{3}$ for $5 \mathrm{~h}$. Structural characterizations of these novel catalysts were carried out by XRD and TEM and results are already reported in Part-I of the present communication [29]. The (99.5-x)wt \%Pd- $0.5 \mathrm{wt} \% \mathrm{C}-\mathrm{x}$ wt $\% \mathrm{Ru}$ (where $\mathrm{x}=0,1,2$, 5,10 , and 20) composites followed the face centered cubic (fcc) crystal geometry, while the composite with $50 \mathrm{wt} \% \mathrm{Ru}$ was amorphous. $\mathrm{Ru}$ addition from 1 to $10 \mathrm{wt} \%$ produced a solid solution of $\mathrm{Ru}$ in $\mathrm{Pd}$, in contrast, $20 \mathrm{wt} \% \mathrm{Ru}$ addition produced a mixed phase containing elemental $\mathrm{Pd}$ and its oxide $(\mathrm{PdO})$ and elemental $\mathrm{Ru}$ and its oxide $\left(\mathrm{RuO}_{2}\right)$. The crystallite sizes ranged between 8 and $11 \mathrm{~nm}$.

For electrochemical studies, the catalyst was produced in the form of a thin layer on the glassy carbon (GC) electrode surface through an ink painting method. For better adherence of the composite film with the GC surface, one drop of $1 \%$ Nafion solution (Alfa Aesar) was dropped over the dried catalyst layer to cover it. The catalyst loaded GC plate was then irradiated with microwave ( 800 watt) for 1 min. Ink was prepared by mixing $8.0 \mathrm{mg}$ of the catalyst with $1.0 \mathrm{ml}$ of ethanol-water mixture (2:1 by volume) ultrasonically as already described elsewhere [29]. Electrical contact with the catalyst overlayer and electrode mounting were made as described previously [30]. The mass of the catalytic films on GC was $0.15-0.23 \mathrm{mg} \mathrm{cm}^{-2}$ and the geometrical surface area of each catalyst electrode was $\sim 0.5 \mathrm{~cm}^{2}$.

Cyclic voltammetry (CV), electrochemical impedance spectroscopy (EIS) and chronoamperometry studies were carried out in a conventional three-electrode single compartment Pyrex glass cell using an electrochemical impedance system (EG \& G, PAR). Pt foil and $\mathrm{Hg} / \mathrm{HgO} / 1 \mathrm{M}$ $\mathrm{KOH}$ were used as the reference and counter electrodes, respectively. The $\mathrm{CV}$ experiments were carried out in the potential range from 0.126 to $1.526 \mathrm{~V} v s$ RHE. Before recording the final voltammogram, each composite electrode was cycled for 5 runs at a scan rate of $50 \mathrm{mVs}^{-1}$ in the electrolyte, in order to obtain a reproducible voltammogram. The EIS study of the electrocatalysts has been carried out in alkaline methanol solutions with the ac voltage amplitude of $10 \mathrm{mV}$ at a constant dc potential. The frequency range employed in the study was $10 \times 10^{3}-0.01 \mathrm{~Hz}$. The equivalent circuit parameters were analyzed by using the software, ZsimpWin. All electrochemical experiments were performed in an $\mathrm{Ar}$ deoxygenated electrolyte at $298 \mathrm{~K}$. The potentials of the working electrode were measured using the reference, $\mathrm{Hg} / \mathrm{HgO} / 1 \mathrm{M} \mathrm{KOH}\left(\mathrm{E}^{\circ}=0.098 \mathrm{~V}\right.$ vs $\left.\mathrm{SHE}\right)$; values given in the text, however, are against the reversible hydrogen electrode, $\operatorname{RHE}\left(\mathrm{E}^{\circ}=-0.828 \mathrm{~V}\right.$ vs $\left.\mathrm{SHE}\right)$.

\section{RESULTS AND DISCUSSION}

\subsection{Cyclic Voltammetry (CV)}

Figs. $(\mathbf{1}, \mathbf{2})$ gather CVs of $(99.5-\mathrm{x}) \mathrm{wt} \% \mathrm{Pd}-0.5 \mathrm{wt} \% \mathrm{C}-\mathrm{x}$ wt $\% \mathrm{Ru}$ at a scan rate of $50 \mathrm{mV} \mathrm{s}^{-1}$ in $1 \mathrm{M} \mathrm{KOH}$ and in $1 \mathrm{M}$ $\mathrm{KOH}+1 \mathrm{M} \mathrm{CH}_{3} \mathrm{OH}$ at $298 \mathrm{~K}$. CVs of the composite electrodes in $1 \mathrm{M} \mathrm{KOH}$ were quite similar; for clarity, only four representative voltammograms for composite with $\mathrm{x}=$ $0,1,5$, and 10 are shown in Fig. (1). Each voltammogram exhibits a strong cathodic peak (at $\mathrm{E} \approx 0.536 \mathrm{~V} v s \mathrm{RHE}$ ) for the reduction of palladium oxide which is formed as a result of oxidation of the Pd surface at E $>0.536 \mathrm{~V}$ vs RHE, in the positive going scan. The potential region between 0.126 and
$0.536 \mathrm{~V} v s$ RHE corresponds to the adsorption-desorption of hydrogen. Similar voltammograms were also found on Pdxwt \% MWCNT (multiwall carbon nanotube) (where $\mathrm{x}=1$, 2 and 5) in $1 \mathrm{M} \mathrm{KOH} \mathrm{[19].} \mathrm{Curves} \mathrm{shown} \mathrm{in} \mathrm{Fig.} \mathrm{(1)} \mathrm{indicate}$ that $\mathrm{Ru}$ addition does not practically change the feature of voltammogram for the base (Pd- $0.5 \mathrm{wt} \% \mathrm{C})$ electrode. Only a new small cathodic peak appears at $\mathrm{E} \approx 0.80 \mathrm{~V} v s$ RHE in case of composites containing $\mathrm{Ru}>1 \mathrm{wt} \%$, the origin of this peak, however, is not very clear. Recently Hoshi et al. [31] and Lee et al. [32] reported that (111) facet of Pd produces two reduction peaks of the palladium oxide. Thus, the two cathodic peaks formed at $\mathrm{E} \approx 0.54$ and $\approx 0.80 \mathrm{~V}$ vs RHE in case of ternary composite electrodes of the present investigation may be ascribed to dominant (111) facet of the Pd metallic phase.

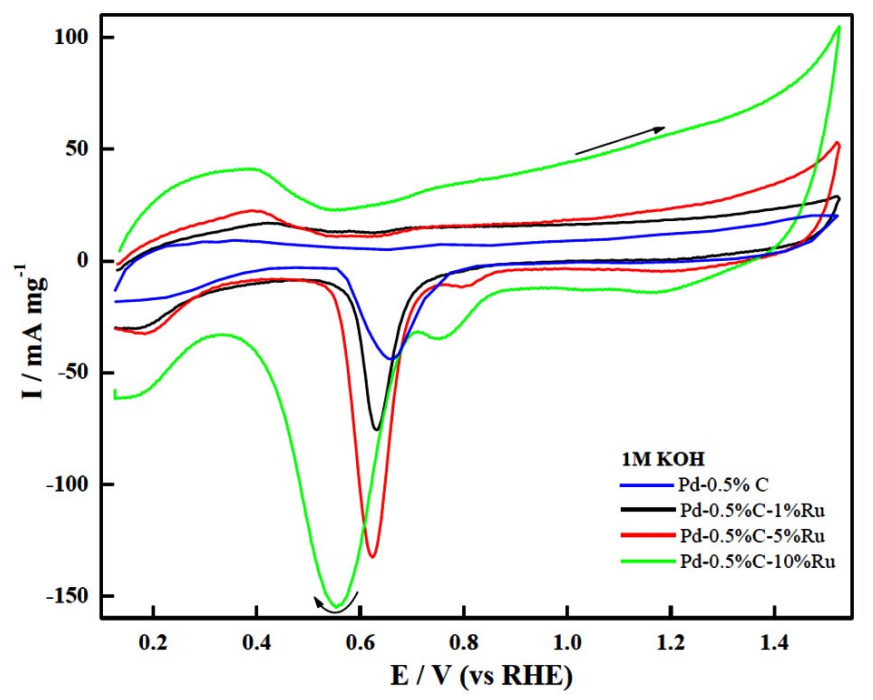

Fig. (1). Cyclic voltammograms of $\mathrm{Pd}-0.5 \mathrm{wt} \% \mathrm{C}-\mathrm{x} \mathrm{wt} \% \mathrm{Ru}(\mathrm{x}=0$, 1,5 and 10) composites in $1 \mathrm{M} \mathrm{KOH}$ at $298 \mathrm{~K}$.

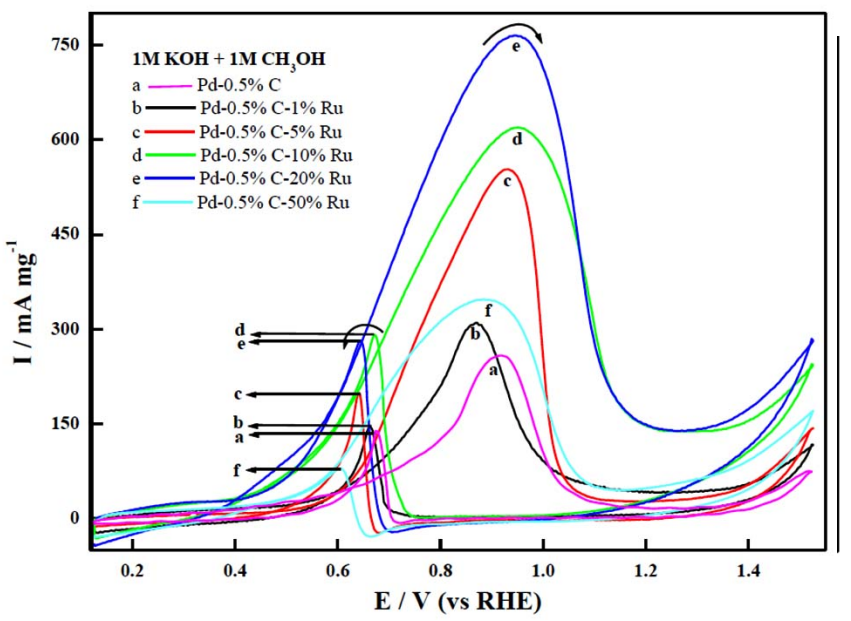

Fig. (2). Cyclic voltammograms of Pd- $0.5 w t \% \mathrm{C}-\mathrm{x}$ wt \% Ru (x = $0,1,5,10,20$ and 50) electrodes in $1 \mathrm{M} \mathrm{KOH}+1 \mathrm{M} \mathrm{CH}_{3} \mathrm{OH}$ at 298 $\mathrm{K}$.

The comparison of CVs of the composite electrodes recorded in the blank solution (1 $\mathrm{M} \mathrm{KOH})$ (Fig. 1) with those obtained in $1 \mathrm{M} \mathrm{KOH}+1 \mathrm{M} \mathrm{CH}_{3} \mathrm{OH}$ (Fig. 2) clearly demonstrates the significant electrooxidation of methanol as indicated by two well defined anodic peaks, one observed on the forward and the other one, observed on the reverse scan. 
Two similar anodic (oxidation) peaks were also obtained when cyclic voltammograms of these composite electrodes were recorded in $1 \mathrm{M} \mathrm{KOH}+1 \mathrm{M} \mathrm{C}_{2} \mathrm{H}_{5} \mathrm{OH}$ under similar experimental conditions [29]. CVs of electrodeposited $\mathrm{Pd}$ on $\mathrm{Ti}$ [33] and Pd-x wt \% Ni (where $\mathrm{x}=1,2,5,10$ and 20) and Pd-10wt \% Ni-x wt \% $\mathrm{C}$ (where $\mathrm{x}=0.5,1,2,5$ and 10 ) composite films on $\mathrm{GC}$ [14] in $1 \mathrm{M} \mathrm{KOH}+1 \mathrm{M}$ $\mathrm{CH}_{3} \mathrm{OH} / \mathrm{C}_{2} \mathrm{H}_{5} \mathrm{OH}$ were also similar to those obtained in the present study. The observed anodic peak on forward scan can be ascribed to oxidation of freshly chemisorbed species derived from adsorption of $\mathrm{CH}_{3} \mathrm{OH}$. At higher potentials, the electrode gets passivated due to the formation of a $\mathrm{Pd}-\mathrm{Ru}$ oxide layer and when the scan is reversed, the oxidized Pd and $\mathrm{Ru}$ species under anodic condition are reduced to elemental $\mathrm{Pd}$ and $\mathrm{Ru}$ and that the oxidation of methanol again takes place on the electrode surface free from oxide, resulting in the anodic current under the cathodic condition [33]. Further, the observed hydrogen adsorption-desorption region (i.e. from 0.126 to $0.426 \mathrm{~V} v s$ RHE) (Fig. 1) appears to be completely suppressed when methanol is present in solution (Fig. 2). This is because of the fact that the onset potentials $\left(\mathrm{E}_{\mathrm{op}}\right)$ for the $\operatorname{MOR}\left(\mathrm{E}_{\mathrm{op}} \approx 0.494-0.382 \mathrm{~V}\right.$ vs $\left.\mathrm{RHE}\right)$ on composite electrodes (Table 1), exactly fall in the potential region wherein the hydrogen adsorption-desorption reactions take place. The latter reactions are dominated by the MOR. In the forward scan, the observed decrease in the oxidation current peak, $I_{p}$ (i.e. self inhibition of alcohol oxidation) can be ascribed to the surface poisoning induced by irreversible strong adsorption of some CO-like species $[34,35]$. The latter gets deposited on the active site of $\mathrm{Pd}$ and thereby inhibits the adsorption of alcohol molecule and hence the rate of its oxidation. At higher potentials, adsorbed $\mathrm{CO}$ species can be effectively removed by reaction with $\mathrm{OH}_{\mathrm{ad}}$ that is produced in the oxygen-adsorption region. CV curves of Fig. (2) were analyzed for the onset potential $\left(E_{o p}\right)$, the peak current $\left(\mathrm{I}_{\mathrm{p}}\right)$, and the peak current potential $\left(\mathrm{E}_{\mathrm{p}}\right)$ and values, so obtained, are listed in Table 1.

Table 1 and Fig. (2) show that introduction of Ru from 1 to $5 \mathrm{wt} \%$ shifts the $\mathrm{E}_{\mathrm{op}}$ for the MOR towards the noble side, however, the magnitude of the shift does not follow a definite trend. The higher addition of $\mathrm{Ru}(10-50 \mathrm{wt} \%)$ somewhat decreases the $\mathrm{E}_{\mathrm{op}}$. This indicates that addition of $\mathrm{Ru}(>5 \mathrm{wt} \%)$ is beneficial from electrocatalysis stand point, which is quite evident from the observed marked increase in the peak current value with progressive addition of $\mathrm{Ru}$ from 1 to $20 \mathrm{wt} \%$. A decline in the peak current, however, takes place at higher Ru additions ( $>20 \mathrm{wt} \%)$.

As the $E_{p}$ value varies with the nature of the electrode, the electrocatalytic activities of ternary composites towards oxidation of methanol have been compared at a common and constant potential, $\mathrm{E}=0.846 \mathrm{~V} v s \mathrm{RHE}$. At this potential, the oxidation current for MOR at each electrode on forward scan was noted and the results, so obtained, are displayed in Fig. (3). This figure clearly demonstrates that the performance of the composite electrode with $20 \mathrm{wt} \% \mathrm{Ru}$ is the best one. This electrode has increased the rate of oxidation of methanol by $\sim 3$ times as compared to that of oxidation of methanol on the base $(\mathrm{Pd}-0.5 \mathrm{wt} \% \mathrm{C})$ electrode. It is noteworthy that under similar experimental conditions, i.e., at $\mathrm{E}=0.726 \mathrm{~V} v s \mathrm{RHE}$ in $1 \mathrm{M} \mathrm{KOH}$ and at $298 \mathrm{~K}$, the electrocatalytic performance of the active electrode Pd- $0.5 \mathrm{wt} \% \mathrm{C}-20 \mathrm{wt} \% \mathrm{Ru}(\mathrm{I} \approx 430 \mathrm{~mA}$ $\left.\mathrm{mg}_{\mathrm{Pd}}{ }^{-1}\right)$ of the present investigation was considerably higher than those of $\mathrm{Pd}_{-\mathrm{Co}_{3}} \mathrm{O}_{4}(2: 1) / \mathrm{C}\left(\mathrm{I} \approx 133 \mathrm{~mA} \mathrm{mg}_{\mathrm{Pd}}{ }^{-1}\right)$ and Pd$\mathrm{Mn}_{3} \mathrm{O}_{4}(2: 1) / \mathrm{C}\left(\mathrm{I} \approx 100 \mathrm{~mA} \mathrm{mg}_{\mathrm{Pd}}{ }^{-1}\right)$ [25], $\mathrm{Pd}-\mathrm{Ni} / \mathrm{C}(\mathrm{I} \approx 380$ $\left.\mathrm{mA} \mathrm{mg}_{\mathrm{Pd}^{-1}}{ }^{-1}\right)$ [35] and $\mathrm{Pd}-\mathrm{NiO}(4: 1) / \mathrm{C}\left(\mathrm{I} \approx 66 \mathrm{~mA} \mathrm{mg}_{\mathrm{Pd}}{ }^{-1}\right)$ [36] electrodes. However, our electrode exhibited slightly lower activity than the electrode, $\mathrm{Pd}-\mathrm{MWCNT}\left(\mathrm{I} \approx 447 \mathrm{~mA} \mathrm{mg}_{\mathrm{Pd}}{ }^{-1}\right)$ [18]. Moreover, the electrocatalytic activity of the latter electrode has been tested in higher concentrations of alcohol $(10 \%)$ and $\mathrm{KOH}(2 \mathrm{M})$.

To examine the role of $\mathrm{Ru}$ in electrocatalysis of the MOR, CV of the Ru- $0.5 w t \% \mathrm{C}$ composite electrode in $1 \mathrm{M}$ $\mathrm{KOH}$ with and without containing $1 \mathrm{M} \mathrm{CH}_{3} \mathrm{OH}$ were also recorded as shown in Fig. (4).The observation of Fig. (4) and Fig. (2) shows that the oxidation of methanol takes place mainly at the Pd sites of the composite electrode.

The electrochemical active surface areas (EASAs) of composite electrodes were also determined by measuring the quantity of electricity ( $Q$ in coulomb, $C$ ) used in the reduction of $\mathrm{PdO}$ formed over the top layer of the $\mathrm{Pd}$ particle, details of which are given elsewhere [20].Values of the EASA (Table 1) were estimated using the relation, $\mathrm{EASA}=\mathrm{Q} / \mathrm{S}$, where ' $\mathrm{S}$ ' is the proportionality constant used to relate charge with area and ' 1 ' is the catalyst loading in ' $\mathrm{g}$ '. A charge value of $405 \mu \mathrm{C} \mathrm{cm} \mathrm{cm}^{-2}(\mathrm{~S})$ is assumed for the reduction of $\mathrm{PdO}$ monolayer. In Table $\mathbf{1}$ and column VII, values of the percent Pd-utilization $(=100 \mathrm{x}$ observed

Table 1. Results of Cyclic Voltammetry of Pd-0.5wt \% C-x wt \% Ru Composite Films in $1 \mathrm{M} \mathrm{KOH}+1 \mathrm{M} \mathrm{CH}$

\begin{tabular}{|c|c|c|c|c|c|c|}
\hline \multirow{2}{*}{$\mathbf{x}$} & \multirow{2}{*}{$\mathbf{E}_{\text {op }} \mathbf{V}$ vs RHE } & \multicolumn{2}{|c|}{ Forward Scan } & \multirow{2}{*}{$\mathrm{Q} / \mathbf{C g}^{-1}{ }{ }^{\prime}$} & \multirow{2}{*}{$\operatorname{EASA} / \mathbf{m}^{2} \mathbf{g}^{-1}$} & \multirow{2}{*}{$\%$ Pd Utilization } \\
\hline & & $\mathrm{E}_{\mathrm{p}} / \mathrm{V} v \boldsymbol{\mathrm { RHE }}$ & $\mathrm{I}_{\mathrm{P}} / \mathbf{m A m g}^{-1}$ Catalyst & & & \\
\hline 1 & 0.494 & 0.867 & 313 & 103.2 & 25.5 & 5.7 \\
\hline 2 & 0.458 & 0.906 & 366 & 206.3 & 50.9 & 11.4 \\
\hline 10 & 0.406 & 0.979 & 615 & 406.9 & 100.5 & 22.4 \\
\hline 20 & 0.385 & 0.935 & 764 & 537.1 & 132.6 & 29.6 \\
\hline 30 & 0.384 & 0.910 & 370 & 265.6 & 65.8 & 14.7 \\
\hline 50 & 0.382 & 0.896 & 356 & 182.6 & 45.1 & 10.1 \\
\hline
\end{tabular}


EASA, $\mathrm{m}^{2} \mathrm{~g}^{-1} / 448 \mathrm{~m}^{2} \mathrm{~g}^{-1}$ ) were estimated by considering the surface area for $100 \%$ utilization of $1 \mathrm{~g}$ Pd as $\sim 448 \mathrm{~m}^{2}(=$ charge required to reduce $1 \mathrm{~g} \mathrm{Pd}^{2+}, 1813.3 \mathrm{C} / 405 \mu \mathrm{C} \mathrm{cm}^{-2}$ ).

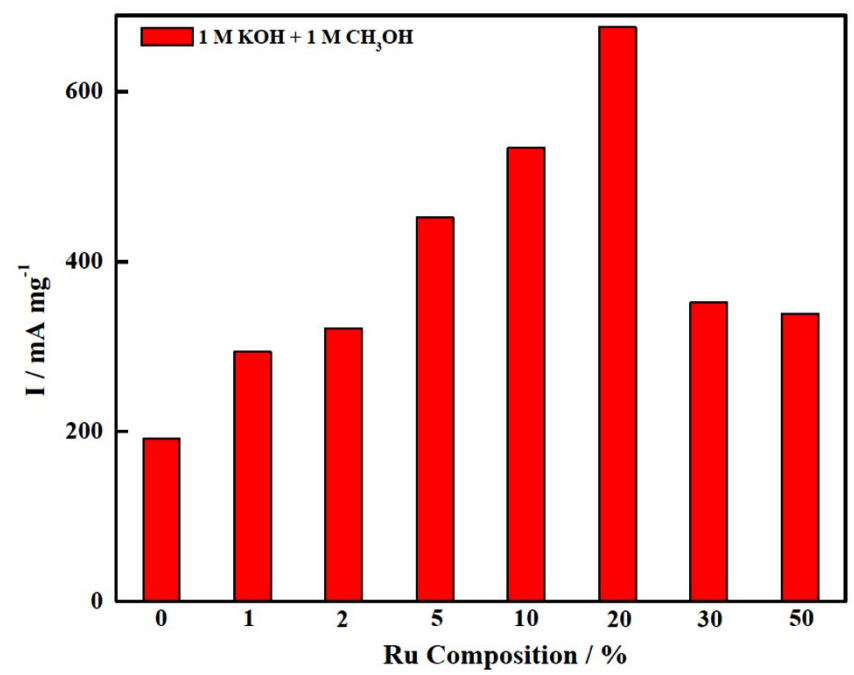

Fig. (3). Comparative electrocatalytic activities of composite electrodes towards methanol oxidation at $\mathrm{E}=0.846 \mathrm{~V} v s \mathrm{RHE}$.

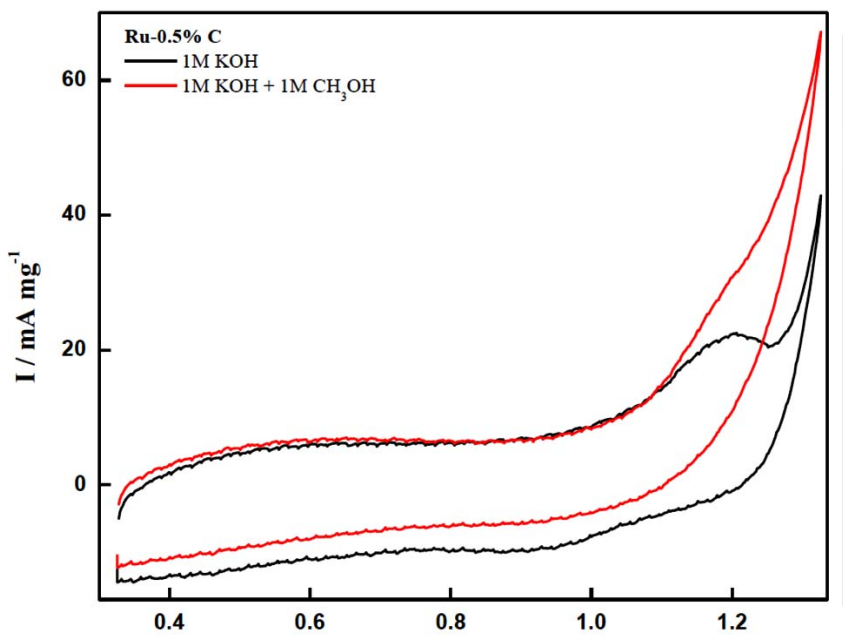

E / V (vs RHE)

Fig. (4). Cyclic voltammograms of Ru- $0.5 \mathrm{wt} \% \mathrm{C}$ in $1 \mathrm{M} \mathrm{KOH}$ with and without containing $1 \mathrm{M} \mathrm{CH}_{3} \mathrm{OH}$ at $298 \mathrm{~K}$.

Table 1 show that with introduction of Ru from 1 to $50 \mathrm{wt}$ $\%$, the EASA as well as the percentage utilization of $\mathrm{Pd}$ initially increase, attain maximum (at $20 \mathrm{wt} \% \mathrm{Ru}$ ) and diminish thereafter. Thus, Ru addition increases the EASA and thereby increases the percentage utilization of Pd and hence the apparent electrocatalytic activity. The decrease in EASA with $\mathrm{Ru}$ addition $>20 \mathrm{wt} \%$ indicates that $\mathrm{Ru}$ blocks some active sites of $\mathrm{Pd}$ at higher additions. Thus, only a certain optimum amount of $\mathrm{Ru}$ in the composite is necessary to produce the greatest electrocatalytic effect in the MOR. Similar result was also obtained in the case of electrooxidation of ethanol [29].

The enhanced catalytic activity of the composite electrodes can be ascribed to the greater affinity of $\mathrm{Ru}$ towards the water molecule forming the surface adsorbed $\mathrm{OH}$ molecule [34]. In fact, compared to Pd, Ru has ability to activate water molecule at a lower potential; this facilitates the formation of $\mathrm{Ru}-\mathrm{OH}$ species and hence the oxidation of adsorbed CO [29, 34]. A significant decrease in the catalytic efficiency of the composite at higher Ru additions $>20 \mathrm{wt} \%$ may be attributed to the phase change of the composite from crystalline to amorphous [29] and also, to blocking of some active sites of Pd by Ru. Thus, results show that Ru addition $>20 \mathrm{wt} \%$ has the detrimental effect on the electrocatalytic performance of the electrode and so, the composites with 30 and $50 \mathrm{wt} \% \mathrm{Ru}$ were not studied further.

\subsection{Electrochemical Impedance Spectroscopy (EIS)}

To investigate the effect of the ruthenium composition variation on the properties of the composite/electrolyte interface (i.e., the double layer capacitance, $\mathrm{C}_{\mathrm{dl}}$ and the catalytic film and the charge transfer resistances) and obtain information regarding electrode kinetics (i.e., reaction rate and Tafel slope) as well as the formation of intermediates, if any, during the methanol oxidation reaction, the impedance study of three ternary composite electrodes, namely $\mathrm{Pd}-$ $0.5 \mathrm{wt} \% \mathrm{C}-5 \mathrm{wt} \% \mathrm{Ru}, \mathrm{Pd}-0.5 \mathrm{wt} \% \mathrm{C}-10 \mathrm{wt} \% \mathrm{Ru}$ and $\mathrm{Pd}-$ $0.5 \mathrm{wt} \% \mathrm{C}-20 \mathrm{wt} \% \mathrm{Ru}$, has been performed in the frequency region from $10 \mathrm{kHz}$ to $10 \mathrm{mHz}$ at constant dc potentials in 1 $\mathrm{M} \mathrm{KOH}+1 \mathrm{M} \mathrm{CH}_{3} \mathrm{OH}$ at $298 \mathrm{~K}$ and results are shown in Fig. (5). Before recording the EI spectrum at a constant dc potential, the electrode was equilibrated for $300 \mathrm{~s}$ at that potential.

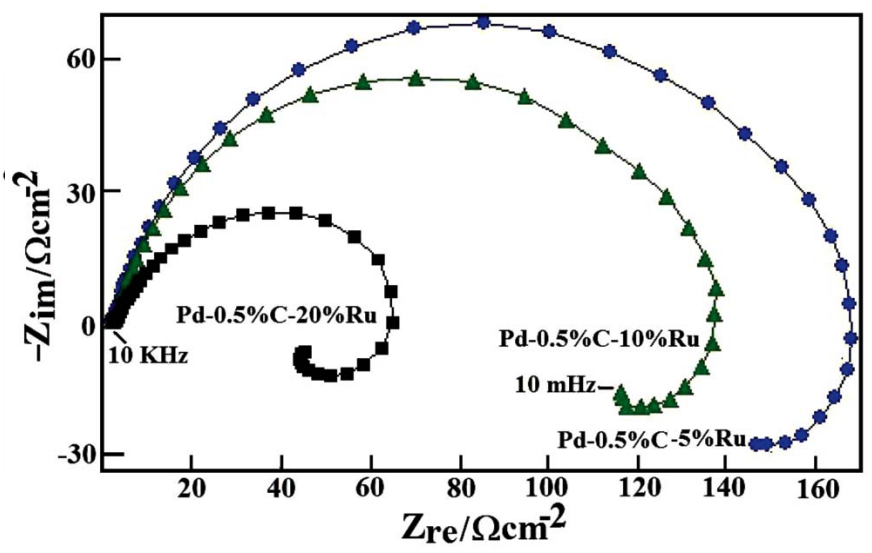

Fig. (5). The Nyquist plots of Pd- $0.5 w t \% \mathrm{C}-\mathrm{x}$ wt \% Ru (x = 5, 10 and 20) composite electrodes at $\mathrm{E}=0.526 \mathrm{~V}$ vs RHE in $1 \mathrm{M} \mathrm{KOH}+$ $1 \mathrm{M} \mathrm{CH}_{3} \mathrm{OH}$.

Features of curves shown in Fig. (5) look to be similar. Each impedance curve has the three distinct parts: a small arc at high, a relatively large semicircle at intermediate and an inductive type loop at low frequencies. Thus, each EI spectrum should have, a minimum, three time constants, $\tau_{1}$, $\tau_{2}$ and $\tau_{3}$, corresponding to high $(10 \mathrm{kHz}-4 \mathrm{kHz})$, intermediate $(4 \mathrm{kHz}-0.5 \mathrm{~Hz})$ and low $(>0.5 \mathrm{~Hz})$ frequency regions, respectively.

Fig. (6) represents EI spectra of the electrode, Pd- $0.5 \mathrm{wt} \%$ $\mathrm{C}-20 \mathrm{wt} \% \mathrm{Ru}$ at four different dc potentials $(0.446,0.476$, 0.506 and $0.526 \mathrm{~V} v s \mathrm{RHE}$ ). It is evident from Fig. (6) that as the working dc potential is increased in positive (noble) direction, the diameter of the semicircle $\left(\tau_{2}\right)$ decreases greatly. The diameter of the semicircle also decreases with an increase of Ru content in the composite Fig. (5). Thus, the results show that the diameter of the semicircle represents 
the charge transfer reaction. The latter is, in fact, a strong function of potential and also varies with the nature of the electrode material.

The observation of Fig. (6) further shows that as potential increases, the diameter of the low frequency inductive loop $\left(\tau_{3}\right)$ decreases. The latter can be attributed to the enhanced desorption of the already adsorbed reaction intermediate (CO) at the electrode surface, particularly at higher potentials. The desorption can increase the active reaction sites and hence, the rate of methanol oxidation reaction [37].

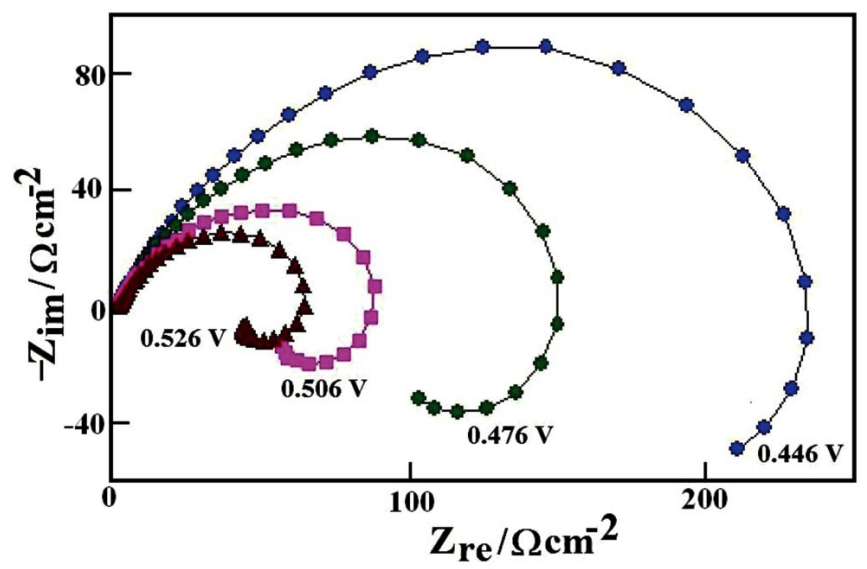

Fig. (6). Nyquist plots of active Pd- $0.5 w t \quad \% \quad \mathrm{C}-20 \mathrm{wt} \% \mathrm{Ru}$ composite electrode at varying dc potentials for MOR in $1 \mathrm{M} \mathrm{KOH}$ $+1 \mathrm{M} \mathrm{CH}_{3} \mathrm{OH}$.

The experimental impedance data were treated with the equivalent circuit model, $\mathrm{R}_{\mathrm{s}}\left(\mathrm{R}_{\mathrm{f}} \mathrm{Q}_{\mathrm{f}}\right)\left(\mathrm{R}_{\mathrm{ct}} \mathrm{Q}_{\mathrm{dl}}\left(\mathrm{LR}_{\mathrm{ads}}\right)\right)$. Symbols, $\mathrm{R}_{\mathrm{s}}, \mathrm{R}_{\mathrm{f}}, \mathrm{R}_{\mathrm{ct}}, \mathrm{R}_{\mathrm{ads}}$ represent the solution, film, charge transfer and adsorption resistances, respectively; $\mathrm{Q}_{\mathrm{f}}$ and $\mathrm{Q}_{\mathrm{dl}}$ represent the constant phase elements (CPE) for the catalyst film and the catalyst/solution interface, respectively; and L represents an inductance and is used to account the impedance contribution of the adsorption and desorption processes taking place at the composite electrode at low frequencies. Similar equivalent circuit was also recently used by Danaee et al. [38] to treat the impedance data of methanol electrooxidation on a $\mathrm{GC} / \mathrm{Ni}$ electrode. It is observed that the simulated impedance data based on proposed circuit model agreed excellently with those experimentally observed ones in the employed frequency range. The simulated and experimental data in the case of active Pd- $0.5 w t \% \mathrm{C}-20 \mathrm{wt} \%$ $\mathrm{Ru}$ electrode in Nyquist representation are shown in Fig. (7) and estimates of the equivalent circuit parameters are given in Tables $\mathbf{2}$ and $\mathbf{3}$.

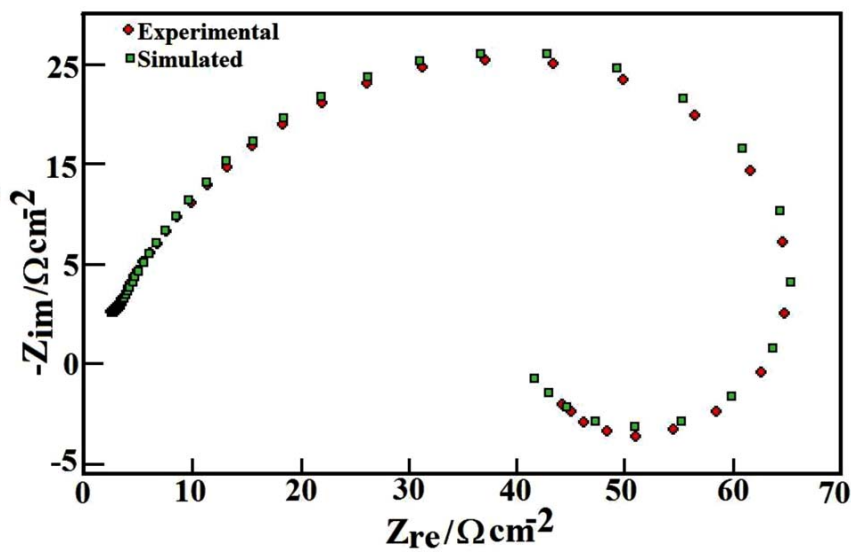

Fig. (7). Experimental and simulated Nyquist plots for Pd- $0.5 w t \%$ $\mathrm{C}-20 \mathrm{wt} \% \mathrm{Ru}$ electrode in $1 \mathrm{M} \mathrm{KOH}+1 \mathrm{M} \mathrm{CH}_{3} \mathrm{OH}$ at $0.526 \mathrm{~V}$ s RHE.

Table 2 shows that the $R_{c t}$ value decreases significantly with increasing $\mathrm{Ru}$ percentage from 5 to $20 \mathrm{wt} \%$ in the composite. As the $\mathrm{R}_{\mathrm{ct}}$ is inversely related to the reaction rate, the rate for the MOR increases with an increase in $\mathrm{Ru}$ introduction into the $\mathrm{Pd}-0.5 \mathrm{wt} \% \mathrm{C}$ composite. This table further shows that 5 and $10 \mathrm{wt} \% \mathrm{Ru}$ do not seem to influence the $\mathrm{C}_{\mathrm{dl}}$, but $20 \mathrm{wt} \% \mathrm{Ru}$ introduction into the $\mathrm{Pd}-0.5 \mathrm{wt} \% \mathrm{C}$ composite enhances the $\mathrm{C}_{\mathrm{dl}}$ approximately 4 times. Thus, the observed highest electrocatalytic activity with the composite containing 20wt\% $\mathrm{Ru}$ in $\mathrm{CV}$ and impedance studies may be ascribed to the enhanced $\mathrm{C}_{\mathrm{dl}}$ (i.e., surface roughness). Thus, the impedance study of electrodes corroborates the results of $\mathrm{CV}$. The significant decrease in $\mathrm{R}_{\mathrm{ads}}$ at the higher potentials

Table 2. Estimates of Equivalent Circuit Parameters for Pd-0.5wt \% C-x wt \% Ru Electrodes in $1 \mathrm{M} \mathrm{KOH}+1 \mathrm{M} \mathrm{CH}$ 0.526 V vs RHE

\begin{tabular}{|c|c|c|c|c|c|c|c|c|c|}
\hline $\mathbf{x}$ & $\mathbf{R}_{s} / \Omega \mathbf{c m}^{2}$ & $\mathbf{R}_{\mathrm{f}} \boldsymbol{\Omega} \mathbf{c m}^{2}$ & $10^{3} \mathrm{Q} / \mathrm{F} \mathrm{s}^{\mathrm{n}-1} \mathrm{~cm}^{-2}$ & $\mathbf{n}$ & $10^{3} \mathrm{Q} / \mathrm{F} \mathrm{s}^{\mathrm{n}-1} \mathrm{~cm}^{-2}$ & $\mathbf{n}$ & $\mathbf{R}_{\mathrm{ct}} \boldsymbol{\Omega} \mathbf{c m}^{2}$ & $\mathbf{L} / \mathbf{H}$ & $\mathbf{R}_{\text {ads }} / \Omega \mathbf{c m}^{2}$ \\
\hline 5 & 2.0 & 1.1 & 3.26 & 0.69 & 1.75 & 0.89 & 166.7 & 5318 & 144.8 \\
\hline 10 & 2.1 & 1.3 & 4.30 & 0.66 & 1.74 & 0.89 & 137.3 & 2688 & 202.5 \\
\hline 20 & 2.5 & 0.6 & 6.01 & 0.68 & 6.63 & 0.77 & 80.61 & 239 & 67.7 \\
\hline
\end{tabular}

Table 3. Equivalent Circuit Parameters for the Pd-0.5wt\% C-20wt\% Ru Electrode in $1 \mathrm{M} \mathrm{KOH}+1 \mathrm{M} \mathrm{CH}_{3} \mathrm{OH}$ at $\mathrm{Varying}$ Applied Potentials

\begin{tabular}{|c|c|c|c|c|c|c|c|c|c|}
\hline E/V vs RHE & $\mathbf{R}_{\mathrm{s}} / \mathbf{\Omega} \mathbf{c m}^{2}$ & $\mathbf{R}_{\mathrm{f}} / \mathbf{\Omega} \mathbf{c m}^{2}$ & $10^{3} \mathrm{Q} / \mathrm{F} \mathrm{s}^{\mathrm{n}-1} \mathrm{~cm}^{-2}$ & $\mathbf{n}$ & $10^{3} \mathrm{Q} / \mathrm{F} \mathrm{s}^{\mathrm{n}-1} \mathrm{~cm}^{-2}$ & $\mathbf{n}$ & $\mathbf{R}_{\mathrm{ct} t} / \mathbf{\Omega} \mathbf{c m}^{2}$ & $\mathbf{L} / \mathbf{H}$ & $\mathbf{R}_{\text {ads }} / \mathbf{\Omega} \mathbf{c m}^{2}$ \\
\hline 0.446 & 2.5 & 0.4 & 2.58 & 0.81 & 6.46 & 0.75 & 283.7 & 5877 & 162.5 \\
\hline 0.476 & 2.5 & 0.3 & 1.73 & 0.85 & 6.53 & 0.74 & 191.4 & 1667 & 115.2 \\
\hline 0.506 & 2.5 & 0.4 & 2.56 & 0.79 & 6.74 & 0.75 & 110.3 & 485 & 74.0 \\
\hline 0.526 & 2.5 & 0.6 & 6.01 & 0.68 & 6.63 & 0.77 & 80.6 & 239 & 67.7 \\
\hline
\end{tabular}


(Table 3) can be caused due to generation of further active sites as a result of desorption of methanol oxidation intermediate (CO) and hence further adsorption of electroactive species, i.e., methanol, on active sites [38]. E was found to vary linearly with $\log \left(\mathrm{R}_{\mathrm{ct}}\right)^{-1}$ (Table 3 ) with the slope $\approx 111 \mathrm{mV}$ (Tafel plot). Similar Tafel slopes (103-114 $\mathrm{mV}$ ) were also found for the MOR on Pd-MWCNT and PdMWCNT-Ni composite electrodes in $1 \mathrm{M} \mathrm{KOH}+1 \mathrm{M}$ $\mathrm{CH}_{3} \mathrm{OH}[20]$.

\subsection{Chronoamperometry}

Chronoamperograms of base and active electrodes, namely Pd- $0.5 \mathrm{wt} \% \mathrm{C}, \mathrm{Pd}-0.5 \mathrm{wt} \% \mathrm{C}-5 \mathrm{wt} \% \mathrm{Ru}, \mathrm{Pd}-0.5 \mathrm{wt} \%$ $\mathrm{C}-10 \mathrm{wt} \% \mathrm{Ru}$, and $\mathrm{Pd}-0.5 \mathrm{wt} \% \mathrm{C}-20 \mathrm{wt} \% \mathrm{Ru}$, recorded at $\mathrm{E}=$ $0.726 \mathrm{~V}$ vs $\mathrm{RHE}$ in $1 \mathrm{M} \mathrm{KOH}+1 \mathrm{M} \mathrm{CH}_{3} \mathrm{OH}$, are shown in Fig. (8). Curves shown in this figure demonstrate that the performance as well as poisoning tolerance of the composite, Pd- $0.5 \mathrm{wt} \% \mathrm{C}-20 \mathrm{wt} \% \mathrm{Ru}$, towards methanol oxidation is the highest among the electrodes investigated.

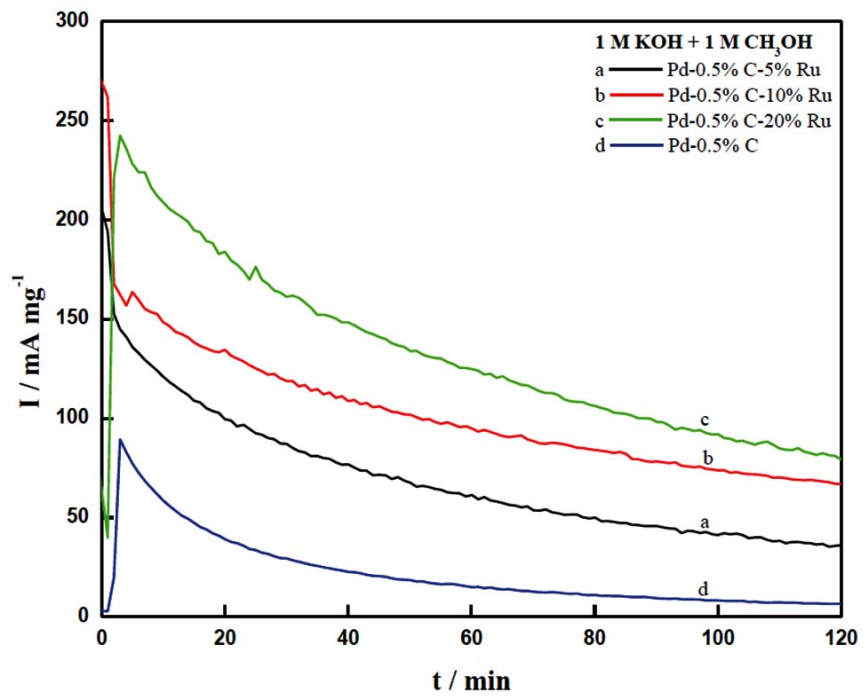

Fig. (8). Chronoamperograms of $\mathrm{Pd}-0.5 \mathrm{wt} \% \mathrm{C}-\mathrm{x}$ wt $\% \mathrm{Ru}(\mathrm{x}=0,5$, 10 and 20) electrodes in $1 \mathrm{M} \mathrm{KOH}+1 \mathrm{M} \mathrm{CH}_{3} \mathrm{OH}$ at $298 \mathrm{~K}$.

Thus, above results have shown that $\mathrm{Ru}$ addition improves both the apparent electrocatalytic activity as well as the poisoning tolerance of the composite electrode. In fact, the methanol electrooxidation reaction is known to proceed through the formation of $\mathrm{CO}$ as intermediate, which inhibits the rate of oxidation reaction by adsorption on $\mathrm{Pd}$ active sites [39]. The presence of $\mathrm{Ru}$ in the composite electrode somewhat activates the water molecules forming the surface adsorbed $\mathrm{OH}$ molecules at a lower potential. The adsorbed $\mathrm{OH}$ molecule, in fact, promotes the oxidation of adsorbed $\mathrm{CO}$ molecule into $\mathrm{CO}_{2}$ and thereby improves the poisoning tolerance of the composite electrode.

\section{CONCLUSIONS}

The study reveals that $\mathrm{Ru}$ introduction from 1 to $50 \mathrm{wt} \%$ in the $\mathrm{Pd}-0.5 \mathrm{wt} \% \mathrm{C}$ composite electrode improves the electrochemical active area as well as the apparent electrocatalytic activity of the electrode towards methanol oxidation reaction; the improvement in electrocatalytic surface properties being the greatest with composite electrode containing $20 \mathrm{wt} \% \mathrm{Ru}$. The latter electrode has demonstrated $\sim 3$ times higher electrocatalytic activity and $\sim$
5 times higher electrochemical active area in comparison with the base electrode ( $\mathrm{Pd}-0.5 \mathrm{wt} \% \mathrm{C})$. The poisoning tolerance of this electrode towards the methanol oxidation intermediate $(\mathrm{CO})$ was also found to be the greatest.

\section{ACKNOWLEDGEMENT}

The financial support received from the Council of Scientific and Industrial Research (CSIR) New Delhi through a research project $(01 / 2320 / 09$-EMR-II) is gratefully acknowledged.

\section{REFERENCES}

[1] Petrii, O.A. Pt-Ru electrocatalysts for fuel cells:a representative review. J. Solid State Electrochem., 2008, 12, 609-642.

[2] Lamy, C.; Rousseau, S.; Belgsir, E. M.; Coutanceau, C.; Leger, J.M. Recent progress in the direct ethanol fuel cell: development of new platinum-tin electrocatalysts. Electrochim. Acta, 2004, 49, 3901-3908.

[3] Singh, R.N.; Awasthi, R.; Tiwari, S.K. Electro-catalytic activities of binary nano-composites of $\mathrm{Pt}$ and nano-carbon/multiwall carbon nanotube for methanol electro-oxidation. Open Catal. J., 2010, 3, 54-61.

[4] Antolini, E. Carbon Support for low-temperature fuel cell catalysts. Appl. Catal. B Environ., 2008, 88, 1-24.

[5] Alcaide, F.; Alvarez, G.; Miguel, O.; Lazaro, M.J.; Moliner, R.; Cudero, A.L.; Gullon, J.S.; Herrero, E.; Aldaz, A. Pt Supported on Carbon nanofibers as electrocatalyst for low temperature polymer electrode membrane fuel cells. Electrochem. Commun., 2009, 11, 1081-1084.

[6] Liang, Y.; Li, J.; Xu, Q.-C.; Hu, R.-Z.; Lin, J.-D.; Liao, D.-W. Characterization of composite carbon supported PtRu catalyst and its catalytic performance for methanol oxidation. J. Alloys Compds., 2008, 465, 296-304.

[7] Tokarz, W.; Siwek, H.; Piela, P.; Czerwinski, A. Electro-oxidation of methanol on Pt-Rh alloys. Electrochim. Acta, 2007, 52, 55655573.

[8] Mukerjee, S.; Urian, R.C.; Lee, S.J.; Ticianelle, E.A.; McBreen, J. Electrocatalysis of $\mathrm{CO}$ tolerance by carbon-supported PtMo electrocatalysts in PEMFCs. J. Electrochem. Soc., 2004, 151, A1094-A1103.

[9] Zhang, J.; Huang, M.; Ma, H.; Tian, F.; Pan, W.; Chen, S. High catalytic activity of nano structured Pd thin films electrochemically deposited on polycrystalline $\mathrm{Pt}$ and $\mathrm{Au}$ substrates towards electrooxidation of methanol. Electrochem. Commun., 2007, 9, 1298-1304.

[10] Dubau, L.; Countanceau, C.; Garnier, E.; Leger, J.-M.; Lamy, C. Electrooxidation of methanol at Platinum-Ruthenium catalysts prepared from colloidal precursors; atomic composition and temperature effects. J. Appl. Electrochem., 2003, 33, 419-429.

[11] Bianchini C.; Shen, P.K. Palladium-Based electrocatalysts for alcohol oxidation in half cells and in direct alcohol fuel cells. Chem Rev., 2009, 109, 4183-4206.

[12] Jafarian, M.; Moghaddam, R.B.; Mahajani, M.G.; Gobal, F. Electro-catalytic oxidation of methanol on a $\mathrm{Ni}-\mathrm{Cu}$ alloy in alkaline medium. J. Appl. Electrochem., 2006, 36, 913-918 and references therein.

[13] Zheng, H.T.; Li, Y.; Chen, S.; Shen, P.K. Effect of support on the activity of Pd electrocatalyst for ethanol oxidation. J. Power Sour., 2006, 163,371-375.

[14] Awasthi, R.; Anindita; Singh, R.N. Synthesis and characterization of nanostructured $\mathrm{Pd}-\mathrm{Ni}$ and $\mathrm{Pd}-\mathrm{Ni}-\mathrm{C}$ composites towards electrooxidation of alcohols. Open Catal. J., 2010, 3, 62-70.

[15] Xu, C.W.; Cheng, L.; Shen, P.K.; Liu, Y.L. Methanol and ethanol electrooxidation on Pt and Pd supported on carbon microspheres in alkaline media. Electrochem. Commun., 2007, 9, 997-1001.

[16] Yuan, D.S.; Xu, C.W.; Liu, Y.L.; Tan, S.; Wang, X.; Wei, Z.; Shen, P.K. Synthesis of coin-like hollow carbon and performance as Pd catalyst support for methanol electrooxidation. Electrochem.Commun., 2007, 9, 2473-2478.

[17] Hu, F.P.; Wang, Z.Y.; Li, Y.L.; Liu, C.M.; Zhang, X.; Shen, P.K. Improved performance of Pd electrocatalyst supported on ultrahigh surface area hollow carbon spheres for direct alcohol fuel cells. $J$. Power Sour., 2008, 177, 61-66. 
[18] Bambagioni, V.; Bianchini, C.; Marchionni, A.; Filippi, Z.; Vizza, F.; Teddy, J.; Serp P.; Zhiani, M. Pd and Pt-Ru anode electrocatalysts supported on multiwalled carbon tubes and their use in passive and active direct alcohol fuel cells with an anionexchange membrane (alcohol $=$ methanol, ethanol, glycerol). $J$. Power Sour., 2009, 190, 241-251.

[19] Singh, R.N.; Singh, A.; Anindita. Electrocatalytic activity of binary and ternary composite films of Pd, MWCNT, and Ni for ethanol electrooxidation in alkaline solutions. Carbon, 2009, 47, 271-278.

[20] Singh, R.N.; Singh, A.; Anindita. Electrocatalytic activity of binary and ternary composite films of Pd, MWCNT, and Ni, Part II; Methanol electrooxidation in $1 \mathrm{M} \mathrm{KOH}$. Int. J. Hydrogen Energy, 2009, 34, 2052-2057.

[21] Xu, C.W.; Wang, H.; Shen, P.K.; Jiang, S.P. Highly ordered pd nanowire arrays as effective electrocatalysts for ethanol oxidation in direct alcohol fuel cells. Adv.Mater., 2007, 19, 4256-4259.

[22] Cheng, F.L.; Wang, H.; Sun, Z.H.; Ning, M.X.; Cai, Z.Q.; Zhang, M. Electrodeposited fabrication of highly ordered $\mathrm{Pd}$ nanowire arrays for alcohol electrooxidation. Electrochem.Commun., 2008, 10, 798-801.

[23] Hu, F.; Ding, F.; Song, S.; Shen, P.K. Pd electrocatalyst supported on carbonized $\mathrm{TiO}_{2}$ nanotube for ethanol oxidation. J. Power Sour., 2006, 163, 415-419.

[24] Zhang, K.-F.; Guo, D.-J.; Liu, X.; Li, J.; Li, H.-L.; Su, Z.-X. Vanadium oxide nanotubes as the support of Pd catalysts for methanol oxidation in alkaline solution. J. Power Sour., 2006, 162, 1077-1081.

[25] Xu, C.; Tian, Z.; Shen, P.K.; Jiang, S.P. Oxide $\left(\mathrm{CeO}_{2}, \mathrm{NiO}, \mathrm{Co}_{3} \mathrm{O}_{4}\right.$ and $\mathrm{Mn}_{3} \mathrm{O}_{4}$ )-promoted $\mathrm{Pd} / \mathrm{C}$ electrocatalysts for alcohol electrooxidation in alkaline media. Electrochim. Acta, 2008, 53, 2610-2618.

[26] Xu, C.; Shen, P.K.; Liu, Y. Ethanol electrooxidation on Pt/C and $\mathrm{Pd} / \mathrm{C}$ catalysts promoted with oxide. J. Power Sour., 2007, 164, 527-531.

[27] Chu, D.; Wang, J.; Wang, S.; Zha, L.; He, J.; Hou, Y.; Yan, Y.; Lin, H.; Tian, Z. High activity of $\mathrm{Pd}-\mathrm{In}_{2} \mathrm{O}_{3} / \mathrm{CNTs}$ electrocatalyst for electro-oxidation of ethanol. Catal.Commun., 2008, 10, 955958.

[28] Singh, R.N.; Singh, A.; Anindita. Electrocatalytic activities of binary and ternary composite electrodes of $\mathrm{Pd}$, nanocarbon and $\mathrm{Ni}$ for electrooxidation of methanol in alkaline medium. J. Solid State Electrochem., 2009, 13, 1259-1265.

[29] Anindita; Awasthi, R.; Madhu; Singh, R.N. Preparation of nanostructured Pd - C- Ru composite electrodes for alcohol electrooxidations. part-i: a study of the ethanol oxidation reaction by cyclic voltammetry and impedance spectroscopy. Open Catal. $J$., (Accepted).

[30] Lal, B.; Singh, N. K.; Samuel, S.; Singh, R. N. Electrocatalytic properties of $\mathrm{Cu}_{\mathrm{x}} \mathrm{Co}_{3-\mathrm{x}} \mathrm{O}_{4}(0 \leq \mathrm{x} \leq 1)$ obtained by a new precipitation method for oxygen evolution. J. New Mater. Electrochem. Syst., 1999, 2, 59-64.

[31] Hoshi, N.; Nakamura, M.; Maki, N.; Yamaguchi, S.; Kitajima, A. Structural effects on voltammograms of the low index planes of palladium and $\mathrm{Pd}(\mathrm{S})-[\mathrm{n}(100) \times(111)]$ surfaces in alkaline solution. J. Electroanal. Chem., 2008, 624,134-138

[32] Lee, Y. W.; Han, S. B.; Park, K. W. Electrochemical properties of $\mathrm{Pd}$ nanostructures in alkaline solution. Electrochem. Commun., 2009, 11, 1968-1971.

[33] Liu, J.; Ye, J.; Xu, C.; Jiang, S.P.; Tong, Y. Kinetics of ethanol electrooxidation at $\mathrm{Pd}$ electrodeposited on Ti. Electrochem. Commun., 2007, 9, 2334-2339.

[34] Selvaraj, V.; Vinoba, M.; Alagar, M.J. Electrocatalytic oxidation of ethylene glycol on Pt and Pt-Ru nanoparticles modified multiwalled carbon nano tubes. Colloid Interface Sci., 2008, 322, 537544.

[35] Liu, Z.; Zhang, X.; Hong, L. Physical and electrochemical characterization of nanostructured $\mathrm{Pd} / \mathrm{C}$ and $\mathrm{PdNi} / \mathrm{C}$ catalyst for methanol oxidation. Electrochem. Commun., 2009, 11, 925-928.

[36] Hu, F.P.; Chen, C.; Wang, Z.Y.; Wei, G.; Shen, P.K. Mechanistic study of ethanol oxidation on $\mathrm{Pd}-\mathrm{NiO} / \mathrm{C}$ electrocatalyst. Electrochim. Acta, 2006, 52, 1087-1091.

[37] Seland, F.; Tunold, R.; Harrington, D.A. Impedance study of methanol oxidation on platinum electrodes. Electrochim. Acta, 2006, 51, 3827-3883.

[38] Danaee, I.; Jafarian, M.; Forouzandeh, F.; Gobal, F.; Mahjani, M.G. Electrochemical impedance studies of methanol oxidation on $\mathrm{GC} / \mathrm{Ni}$ and $\mathrm{GC} / \mathrm{NiCu}$ electrode. Int. J. Hydrogen Energy, 2009, 34, 859-869.

[39] Casella, I.G. Electrooxidation of aliphatic alcohols on palladium oxide catalyst prepared by pulsed electrodeposition technique. Electrochim. Acta, 2009, 54, 3866-3871.

(C) Anindita et al.; Licensee Bentham Open.

This is an open access article licensed under the terms of the Creative Commons Attribution Non-Commercial License (http://creativecommons.org/licenses/by-nc/ 3.0/) which permits unrestricted, non-commercial use, distribution and reproduction in any medium, provided the work is properly cited. 